\title{
Numerical investigation of the thermocapillary migration of a water droplet in a microchannel by applying heat source
}

\author{
Le Thanh Long ${ }^{1,2,3,}{ }^{*}$, Jyh Chen Chen ${ }^{4}$, Nguyen Huy Bich ${ }^{5}$
}

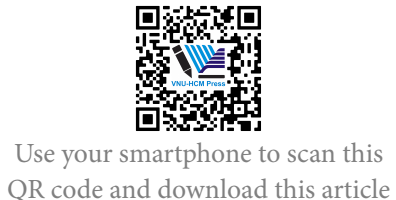

QR code and download this article
${ }^{1}$ Faculty of Mechanical Engineering, Ho Chi Minh City University of Technology (HCMUT), 268 Ly Thuong Kiet Street, District 10, Ho Chi Minh City, Vietnam

${ }^{2}$ National Key Laboratory of Digital Control and System Engineering (DCSELab), HCMUT, 268 Ly Thuong Kiet Street, District 10, Ho Chi Minh City, Vietnam

${ }^{3}$ Vietnam National University Ho Chi Minh City, Linh Trung Ward, Thu Duc District, Ho Chi Minh City, Vietnam

${ }^{4}$ Department of Mechanical Engineering, National Central University, Jhongli 320, Taiwan

${ }^{5}$ Faculty of Engineering and Technology, Nong Lam University, Ho Chi Minh City, Vietnam

\section{Correspondence}

Le Thanh Long, Faculty of Mechanical Engineering, Ho Chi Minh City University of Technology (HCMUT), 268 Ly Thuong Kiet Street, District 10, Ho Chi Minh City, Vietnam

National Key Laboratory of Digital Control and System Engineering (DCSELab), HCMUT, 268 Ly Thuong Kiet Street, District 10, Ho Chi Minh City, Vietnam

Vietnam National University Ho Chi Minh City, Linh Trung Ward, Thu Duc District, Ho Chi Minh City, Vietnam

Email: Itlong@hcmut.edu.vn

\section{ABSTRACT}

The migration of a small droplet has been developed during the last two decades due to its applications in industry and high technology such as MEMS and NEMS devices, Lap-On-a- chip, transportation of fluids and so on. There have many studies in this topic in which the energy source as driving force for moving of a droplet is quite difference like heating, magnetics, pressure, electric, laser and so on. In this study, the numerical computation is used to investigate the transient thermocapillary migration of a water droplet in a micro-channel under the effect of heating source. For tracking the evolution of the free interface between two immiscible fluids, we employed the finite element method with the two-phase level set technique to solve the Navier-Stokes equations and continuity equation coupled with the energy equation. Both the upper wall and the bottom wall of the microchannel are set to be an ambient temperature. $40 \mathrm{~mW}$ heat source is placed at the distance of $1 \mathrm{~mm}$ from the initial position of a water droplet. When the heat source is turned on, a pair of asymmetric thermocapillary convection vortices is formed inside the droplet and the thermocapillary on the receding side is smaller than that on the advancing side. The temperature gradient inside the droplet increases quickly at the initial times and then decreases versus time. Therefore, the actuation velocity of the water droplet first increases significantly, and then decreases continuously. Furthermore, the results also indicate that the dynamic contact angle is strongly affected by the oil flow motion and the net thermocapillary momentum inside the droplet. The advancing contact angle is always larger than the receding contact angle during actuation process.

Key words: Numerical simulation, thermocapillary migration, microchannel, surface tension, heat source

\section{INTRODUCTION}

Recently, microfluidics technique has significantly attracted owing to its diverse applications in Lab-on-a Chip devices (LOC), Micro-Electro-Mechanical System (MEMS) or protein crystallization ${ }^{1-3}$. The thermocapillary migration is a great important to manipulate the droplet behavior and optimize the performance of the behavior of the droplet-based microfluidics ${ }^{4,5}$. The droplet transport behavior in a microchannel actuated by a transient temperature gradient has already been investigated in numerous studies $^{6-14}$. Brochard ${ }^{6}$ indicated that the contact angle of a liquid droplet at rest, static contact angle (SCA), is altered to the dynamic contact angle (DCA) when the droplet moves on a solid surface. The difference in the DCA between the advancing and receding sides, so-called contact angle hysteresis (CAH), is strongly affected by the temperature gradient.

The experimental results of Chen et al. ${ }^{7}$, developed from Ford and Nadim's work ${ }^{8}$, indicated that a fixed $\mathrm{CAH}$ influences the droplet velocity and threshold values much more significantly than the slip length.
Le et al. ${ }^{9}$ showed the effect of upper wall condition on the liquid droplet migration behavior in a microchannel. The movement of a liquid droplet in a microchannel is strengthened due to the net thermocapillary momentum generated by the unequal size of the two vortices inside the droplet. The results showed the actuation velocity and the DCA of the droplet are strongly affected by the thermal condition of upper wall. In addition, the numerical results from Le et al. ${ }^{10}$ demonstrated that the silicone plug motion inside capillary tube is influenced by the net thermocapillary momentum generated by the temperature gradient along the gas-liquid interface and the capillary force caused by the temperature difference between the ends of the liquid plug. The numerical results are in good agreement with the previous experimental results ${ }^{11}$. Liu et al. ${ }^{12}$ developed a lattice Boltzmann phase-field model to numerically simulate the thermocapillary flows in a microchannel. Their results indicated that the contact angle strongly influences the droplet dynamic behavior and the droplet motion driven by shear flow at the inlet of a confined microchannel is completely blocked by using a laser 
History

- Received: 12/ 10/2018

- Accepted: 24/11/2018

- Published: 31/12/2019

DOI : 10.32508/stdjet.v3iSI1.716

\section{Check for updates}

Copyright

(C) VNU-HCM Press. This is an openaccess article distributed under the terms of the Creative Commons Attribution 4.0 International license.

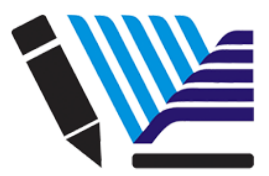

VNU-HCM Press source to heat the fluids at the advancing side of a droplet. Recently, Le et al. ${ }^{13}$ studied the droplet migration behavior in a microchannel under a blocking effect from the heated upper wall. Their results showed that thermocapillary momentum assists the droplet movement when the smallest temperature on the free interface of a liquid droplet shifts from the mid-plane to the advancing side. The thermocapillary momentum then resist the movement of droplet as the highest temperature appears on the free interface. Moreover, the capillary force also strongly affects the droplet migration.

For lab-on-a-chip (LOC) applications, a drop could be flexibly manipulated the motion directions. The experimental work of Vincent et al. ${ }^{14}$ investigated the localized thermocapillary stresses on the interface of flowing droplets subjected to the laser source. Their results indicated that high velocity droplet switching and sorting in a microchannel depends on laserinduced thermocapillary stresses. It is very interesting to use numerical methods to investigate the thermocapillary migration of a liquid droplet in a microchannel under heat source and then verify the experimental results. It has not been well studied.

\section{METHODOLOGY}

A small water droplet is placed at the bottom solid wall in a microchannel with a cross-sectional area $\mathrm{H} \times \mathrm{W}$ in which $\mathrm{H}$ is the height and $\mathrm{W}$ is the length of the microchannel. The shape of the liquid droplet is initially assumed to be that of a cylindrical cap with a static contact angle $\theta$, maximum height $\mathrm{h}_{m}$, and footprint radius $\mathrm{L}$ (Figure 1 ). Both the upper wall and the bottom wall of the microchannel are subjected to an ambient temperature. Since the droplet is considered to be very small in size, the influence from the body force can be neglected. The properties of the fluids are listed in Table 1.

Numerical simulations are used to investigate the thermocapillary actuation behavior of a water droplet in a microchannel under a heat source. The numerical methods for predicting the liquid migration must be able to track the movement and deformation of the interface. The conservative level set method ${ }^{15,16}$ is commonly used to deal with the deformation of the free interface during the droplet motion. In this method, the hexadecane subdomain $\Omega_{1}$ and the water droplet subdomain $\Omega_{2}$ are separated by the interface $S(x)$ with the level set function $\Phi=0.5$. The value of $\Phi$ goes smoothly from 0 to 1 with $0 \leq \Phi<0.5$ in the water droplet subdomain $\Omega_{2}$ and $0.5<\Phi \leq 1$ in the hexadecane subdomain $\Omega_{1}$ (Figure 1). The equation describing the interface reinitialized convection is written as: $\frac{\delta \phi}{\delta t}+V_{i} \nabla \phi=\lambda \nabla \cdot\left[\varepsilon \nabla \phi-\phi(1-\phi) \frac{\nabla \phi}{|\nabla \phi|}\right]$

Where $\lambda$ denotes the amount of reinitialization parameter, $\varepsilon$ determines the thickness of the layer around the interface and $\mathrm{V}_{i}$ is the velocity vector. The dense mesh must be located near the free interface during migration to ensure the accuracy of the numerical simulations. The ALE technique is used to ensure that the fine mesh moves simultaneously with the interface. The finite element method developed by Comsol Multiphysics is used to solve the governing equations with the correlative boundary and initial conditions, employing second-order Lagrange triangular elements. The dependency of the element number on the simulation results has been determined to ensure the accuracy of the solution.

The two-dimensional equations for the conservation of mass, momentum, and energy for Newtonian incompressible fluids are written as:

$\left[\frac{\delta u}{\delta x}+\frac{\delta v}{\delta z}\right]_{i}=0$

$p_{i}\left[\frac{\delta u}{\delta t}+u \frac{\delta u}{\delta x}+v \frac{\delta u}{\delta z}\right]_{i}=-\frac{\delta p}{\delta x}+\mu_{i}\left[\frac{\delta^{2} u}{\delta x^{2}}+\frac{\delta^{2} u}{\delta z^{2}}\right]_{i}+$ $F_{x}$ (3)

$p_{i}\left[\frac{\delta v}{\delta t}+u \frac{\delta v}{\delta x}+v \frac{\delta v}{\delta z}\right]_{i}=-\frac{\delta p}{\delta z}+\mu_{i}\left[\frac{\delta^{2} v}{\delta x^{2}}+\frac{\delta^{2} u}{\delta z^{2}}\right]_{i}+$ $F_{z}$

$\rho_{i} C_{\rho_{i}}\left[\frac{\delta T}{\delta t}+u \frac{\delta T}{\delta x}+v \frac{\delta T}{\delta z}\right]_{i}=k_{i}\left[\frac{\delta^{2} T}{\delta x^{2}}+\frac{\delta^{2} T}{\delta z^{2}}\right]_{i}+$ $Q_{s}$

Where $\mathrm{u}_{i}$ and $\mathrm{v}_{i}$ are the velocity components in the $\mathrm{x}$ and $\mathrm{z}$ - directions, respectively; $\mathrm{p}$ is the pressure and $\rho_{i}$ is the fluid density; $\mu_{i}$ is the dynamic viscosity; $\mathrm{C}_{P i}$ is the specific heat; $\mathrm{k}_{i}$ is the thermal conductivity; and $\mathrm{T}$ is the temperature. The subscripts $\mathrm{i}=$ "w" and $\mathrm{i}=$ "o" represent water and hexadecane oil, respectively. $\mathrm{F}_{x}$ and $\mathrm{F}_{z}$ are the surface tension force in the $\mathrm{x}$ - and $\mathrm{z}$ directions, respectively. $\mathrm{Q}_{s}$ is the heat source.

The dependence of fluids density on temperature can be expressed as

$\rho_{i}=\rho_{\text {ref } i}\left(1-\beta_{i}\left(T_{i}-T_{\text {ref }}\right)\right)$

Where $\rho_{\text {ref }}$ is the fluid density at the reference temperature, and $\beta_{i}$ is the thermal expansion coefficient of the fluid.

The continuum surface force method developed by Brackbill et al. ${ }^{17}$ is used to deal with the existence of the surface tension along the free interface. The surface tension force at the free interface can be modeled by

\section{$F=\sigma \chi \delta n$}

Where $\sigma$ is the surface tension; $\delta$ is the Dirac delta function that is a nonzero value at the droplet/air interface only; $\mathrm{n}$ is the unit normal vector to the interface; and $\kappa$ is the local interfacial curvature. The surface tension $\sigma$ can be assumed to vary linearly with temperature $^{18}$, i.e. 


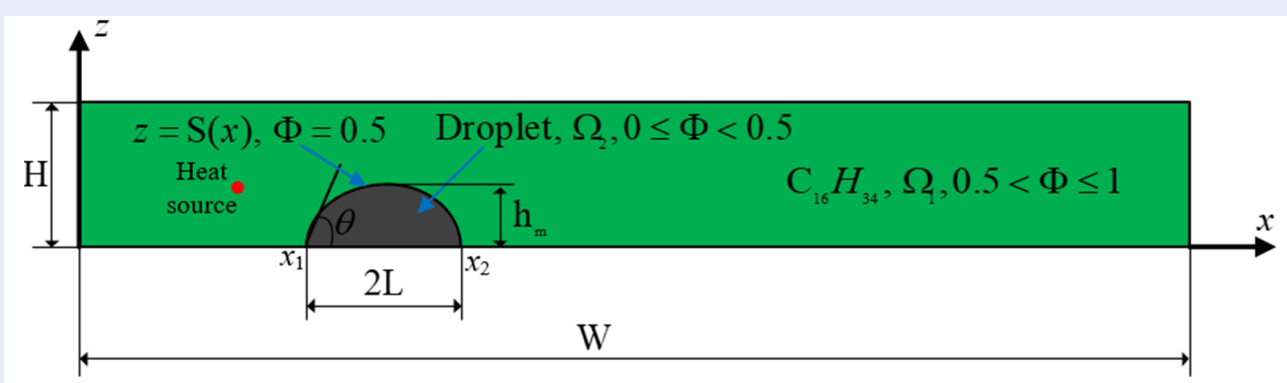

Figure 1: Schematic representation used for computation. The value of the level set function $\Phi$ is equal to 0.5 at the hexadecane/droplet interface. The hexadecane (subdomain $\Omega_{1}$ ) and the water (subdomain $\Omega_{2}$ ) are represented by $0.5<\Phi \leq 1$ and $0 \leq \Phi<0.5$, respectively.

\begin{tabular}{lll}
\multicolumn{3}{l}{ Table 1: Physical properties of the fluids (at 298K) } \\
\hline Parameter & Water & $\begin{array}{l}\text { Hexadecan Oil } \\
\left(\mathrm{C}_{16} \mathbf{H}_{34}\right)\end{array}$ \\
$\rho(\mathrm{kg} / \mathrm{m} 3)$ & 998.23 & 775 \\
$\sigma(\mathrm{N} / \mathrm{m})$ & $71.8 \times 10-3$ & $28.12 \times 10-3$ \\
$\gamma_{T}(\mathrm{mN} / \mathrm{m} . \mathrm{K})$ & 0.1514 & 0.06 \\
$\mu(\mathrm{Pa} . \mathrm{s})$ & $9 \times 10-4$ & 0.003 \\
$\alpha\left(\mathrm{m}^{2} / \mathrm{s}\right)$ & $1.458 \times 10-7$ & $3.976 \times 10-7$ \\
$\mathrm{k}(\mathrm{W} / \mathrm{m} . \mathrm{K})$ & 0.6084 & 0.154 \\
$\mathrm{CP}(\mathrm{J} / \mathrm{kg} . \mathrm{K})$ & 4181.3 & 499.72 \\
\hline
\end{tabular}

$\sigma=\sigma_{r e f}-\gamma_{t}\left(T-T_{r e f}\right)$

Where $\sigma_{\text {ref }}$ is the surface tension at the reference temperature $\mathrm{T}_{r e f}$ and $\gamma_{T}=\frac{\delta \sigma}{\delta T}$ is the coefficient of the surface-tension.

The boundary conditions for the flow and temperature field are given by :

$p=p_{o}, \frac{\delta u_{o}}{\delta x}=0, \frac{\delta T_{o}}{\delta x}=0$ at $x=0$ and $x=$ $W \quad(9)$

$\mathrm{u}_{o}=\mathrm{v}_{o}=0, \mathrm{~T}_{o}=\mathrm{T}_{r e f}$ at $0<\mathrm{x}<\mathrm{W}, \mathrm{z}=\mathrm{H},(10)$

$\mathrm{u}_{o}=\mathrm{v}_{o}=0$ at $0<\mathrm{x}<\mathrm{x}_{1}$ and $\mathrm{x}_{2}<\mathrm{x}<\mathrm{W}, \mathrm{z}=0,(11)$

$T_{i}=T_{\text {ref }}$ at $0 \leq x \leq W, z=0$

Where $x_{1}$ and $x_{2}$ are location of the droplet's two contact points. The Navier slip condition is applied at the water-solid and oil-solid boundary

$u_{\tau}=b_{i s} \frac{\delta u}{\delta z}$

Where $b_{i s}$ is the slip length. The order of slip length $\mathrm{b}_{i s}$ depends on the roughness of solid surface and the type of fluid flow and it can be determined by the experiments or molecular dynamics simulations. Its order is a few nanometers ${ }^{19,20}$. The water/oil interface $\mathrm{S}(\mathrm{x})$ is set to ensure the continuum of flow and temperature

$V_{w} . \nabla S=V_{o} . \nabla S, T_{o}=T_{w}$

(14) where $V=u i+v j$.
Before a thermal gradient is imposed on the bottom wall, the droplet is placed on the wall at $\mathrm{x}=2.5 \mathrm{H}$ in the ambient temperature. Thus, the initial conditions are set as the following equations:

$V_{w}(X, 0)=V_{o}(X, 0)=0$

$T_{\text {sub }}(x, 0,0)=T_{\text {ref }}$

$T_{w}(X, 0)=T_{o}(X, 0)=T_{r e f}$

where $X=x i+z j$

\section{RESULTS AND DISCUSSION}

The water droplet actuated in a microchannel is selected to be $\theta=90^{\circ}, \mathrm{T}_{w, o}=298 \mathrm{~K}, \mathrm{~L}=0.55 \mathrm{~mm}$, and $\mathrm{h}_{m}=0.55 \mathrm{~mm}$. Figure 2 shows the evolution of streamlines and isotherms with time with $\mathrm{b}_{s}=1$ $\mathrm{nm}, \mathrm{W}=10 \mathrm{~mm}$, and $\mathrm{H}=1 \mathrm{~mm}$. Both the upper wall and the bottom wall of the microchannel are set to be an ambient temperature. $40 \mathrm{~mW}$ heat source is placed at the distance of $1 \mathrm{~mm}$ from the initial position of a water droplet. The imbalance in the surface tension along the free surface causes two thermocapillary vortices inside and outside the liquid droplet. The total strength of these vortices on the hot (left) side is larger than on the cold (right) side due to higher temperature gradient. The thermocapillary migration 
results in the net thermocapillary momentum which drives the liquid droplet moves from the hot side of the open channel to the cold side. In addition, the flow motion in oil solution strongly affects the droplet migration. At the initial stage, the size and strength of thermocapillary vortice on the receding side of the droplet are small. The heat energy transfers from the heat source to the droplet. As the time passes, the size and strength of thermocapillary vortices on the receding side get larger while they get smaller on the advancing side. The isotherms inside the droplet are extremely distorted by the thermocapillary convection. The temperature distribution in the oil region is the concentric circles diffused to the droplet and distorted when it bumps against the droplet. The highest temperature of the droplet is located at the free interface during actuation process. The location of the highest temperature on the free interface moves from the rear contact line towards the apex of the interface.

Figure 3: illustrates the temperature gradients inside the droplet on the receding $\left(\Delta \mathrm{T}_{R}\right)$ and advancing $\left(\Delta \mathrm{T}_{A}\right)$ sides. The temperature gradient on the receding and advancing side are defined by $\triangle T_{R}=$ $T_{\max }-T_{R}$ and $\triangle T_{A}=T_{\max }-T_{A}$, respectively. Where $\mathrm{T}_{\max }$ is the highest temperature of the droplet; $\mathrm{T}_{R}$ and $\mathrm{T}_{A}$ is the temperature of the liquid droplet which is located at the rear and front contact line, respectively. The temperature gradients increase rapidly first and then decreases continuously. This means thermocapillary convection increases at the initial stage and decreases when the time increases to a certain value. The temperature gradient inside the droplet on the receding side is always smaller than that on the advancing side during actuation process. It leads to the thermocapillary force assists the movement of the droplet in a microchannel.

Figure $4 \mathrm{a}$ shows the evolution of the silicone droplet position in a microchannel versus time with $\mathrm{b}_{s}=1$ $\mathrm{nm}, \theta=90^{\circ}, \mathrm{W}=10 \mathrm{~mm}$, and $\mathrm{H}=1 \mathrm{~mm}$. The tendency of silicone droplet velocity versus time is also plotted in Figure 4b. The actuation velocity of the liquid droplet first increases significantly, and then decreases dramatically. According to Nguyen and Chen ${ }^{21-23}$, the actuation of the behavior of the droplet depends on the net momentum of thermocapillary convection created inside the droplet. The Marangoni number (Ma) represents the strength of thermocapillary convection, which is proportional to the temperature difference inside the droplet. As a consequence, the Ma increases rapidly first and then decreases continuously when time reaches to a certain value.

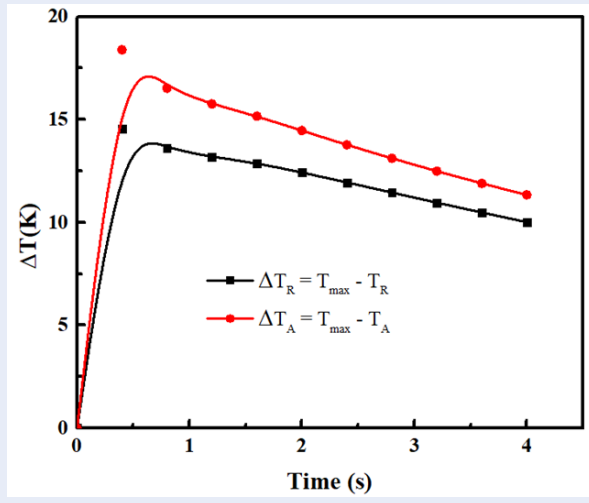

Figure 3: Temperature gradient inside the droplet on the receding $\left(\Delta \mathbf{T}_{R}\right)$ and advancing $\left(\Delta \mathbf{T}_{A}\right)$ sides versus time with $\mathbf{b}_{s}=1 \mathrm{~nm}, \theta=90^{\circ}$, $W=10 \mathrm{~mm}$, and $\mathrm{H}=1 \mathrm{~mm}$.

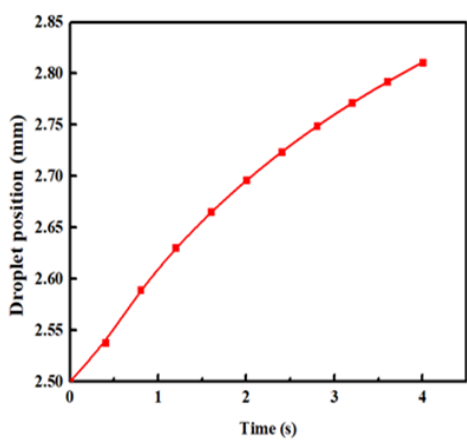

(b)

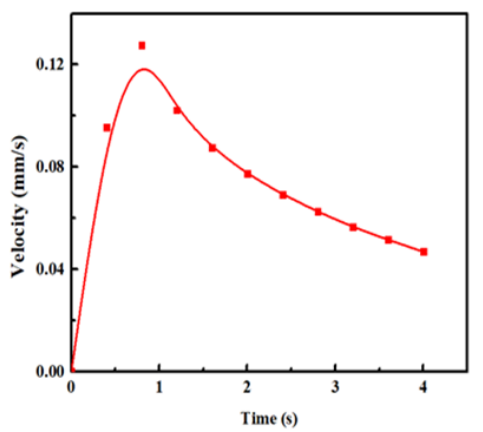

Figure 4: (a) Displacement and (b) droplet actuation velocity versus time with $b_{s}=1 \mathrm{~nm}, \theta=90^{\circ}$, $W=10 \mathrm{~mm}$, and $\mathrm{H}=\mathbf{1} \mathbf{m m}$. 
(a)

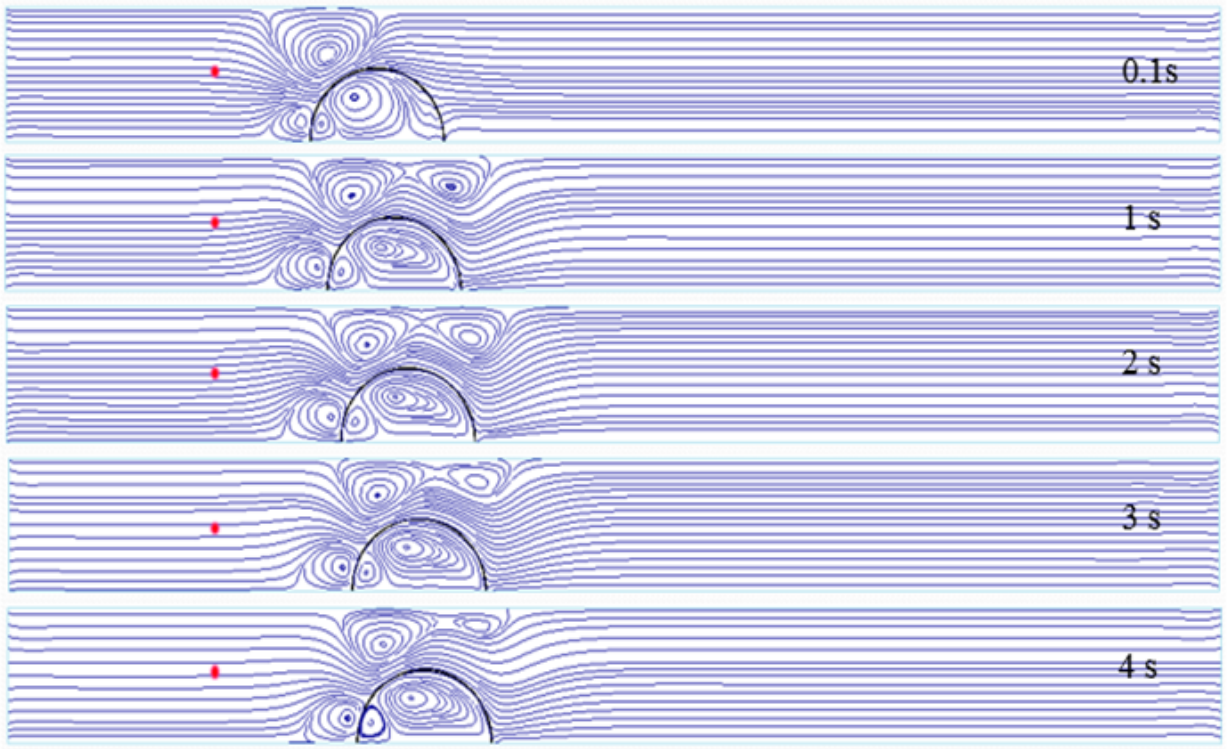

(b)

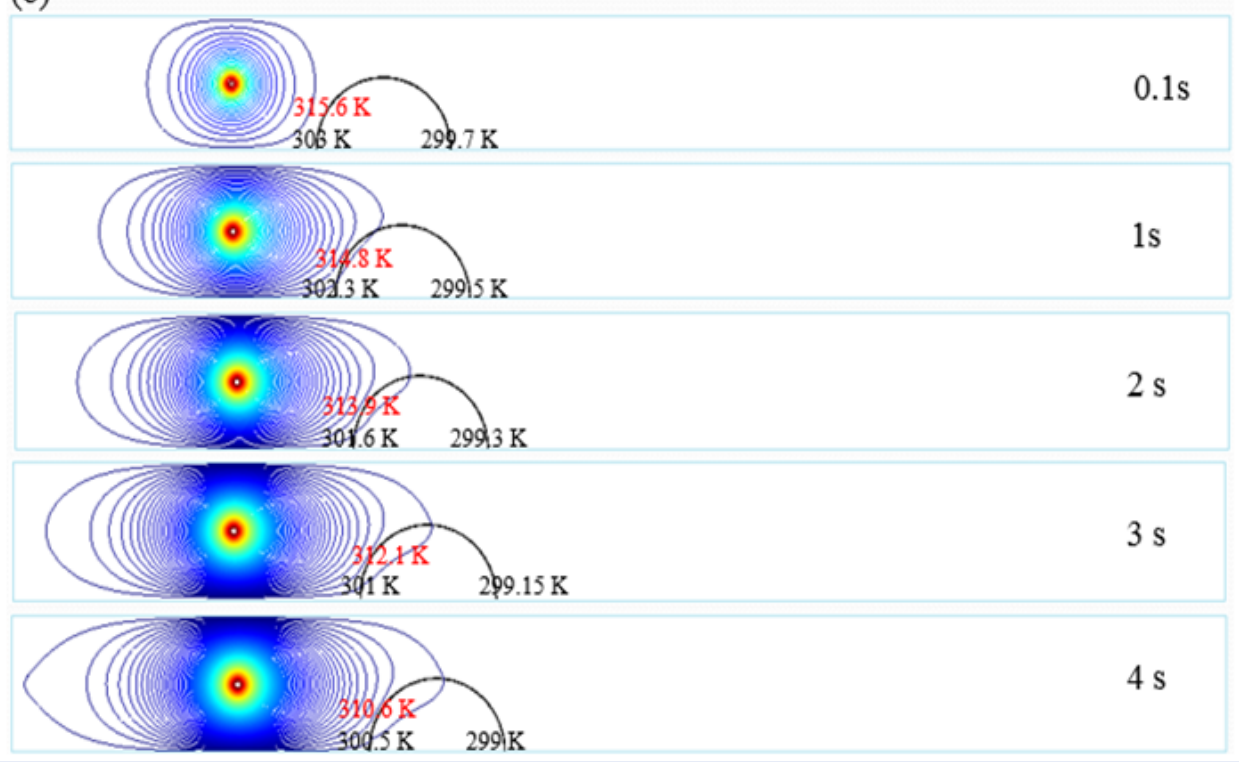

Figure 2: (a) Streamlines and (b) isotherms inside thechannel at different times with $\mathbf{b}_{s}=\mathbf{1} \mathbf{n m}, \theta=90^{0}, \mathbf{W}$ $=10 \mathrm{~mm}$, and $\mathrm{H}=1 \mathrm{~mm}$.

Figure 5 shows the pressure differences $\left(\Delta \mathrm{P}=\mathrm{p}_{w^{-}}\right.$ $\mathrm{p}_{o}$ ) on both side of the droplet and the variation of DCA during the migration process with $\mathrm{b}_{s}=1 \mathrm{~nm}$, $\theta=90^{\circ}, \mathrm{W}=10 \mathrm{~mm}$, and $\mathrm{H}=1 \mathrm{~mm}$. The pressure difference at the receding $\left(\Delta \mathrm{P}_{R}\right)$ and the advancing side $\left(\Delta \mathrm{P}_{A}\right)$ of the droplet is negative and positive, respectively (Figure $5 \mathrm{a}$ ). The present results show that the DCA alternates during the actuation process (Figure 5b). The DCA behavior strongly depends on the pressure difference acting on the droplet. The re- ceding contact angle (RCA, $\theta_{R}$ ) decreases strongly first and then increases significantly while the advancing contact angle (ACA, $\theta_{A}$ ) increases rapidly first and then decrease continuously. The ACA is always larger than the RCA due to the magnitude of $\Delta \mathrm{P}_{A}$ is smaller than that of $\Delta \mathrm{P}_{R}$. Since $\theta_{A}>90>\theta_{R}$ and $\sigma_{A}>$ $\sigma_{R}, \sigma_{A} \cos \theta_{A}-\sigma_{A} \cos \theta_{A}<0$. Therefore, the capillary force acts against the movement of the water droplet in a microchannel. 


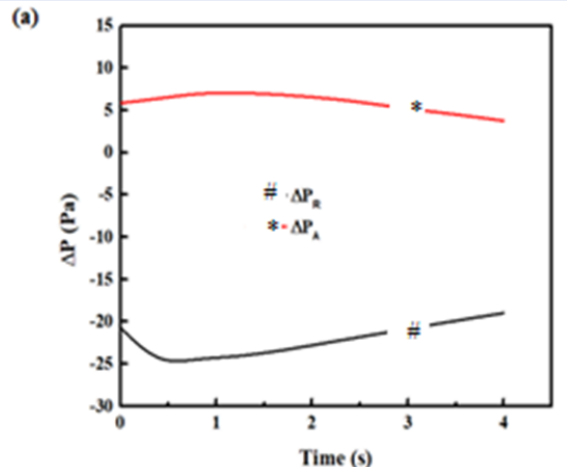

(b)

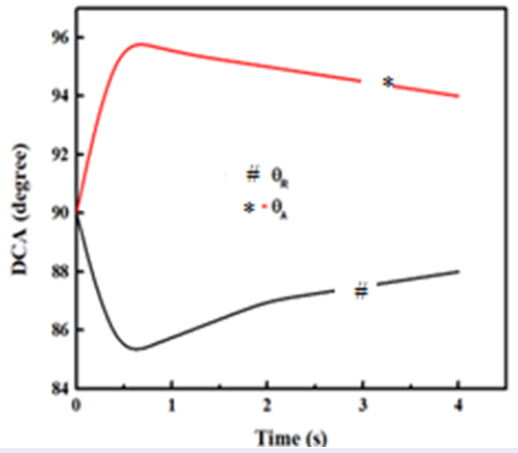

Figure 5: (a) The pressure differences on both sides of a water droplet and (b) dynamic contact angle during the actuation process with $\mathbf{b}_{s}=1$ $\mathrm{nm}, \theta=90^{\circ}, \mathrm{W}=10 \mathrm{~mm}$, and $\mathrm{H}=1 \mathrm{~mm}$.

\section{CONCLUSION}

The transient thermocapillary migration of a water droplet in a microchannel subjected to a heat source has been investigating numerically. Both the upper wall and the bottom wall of microchannel are set to be an ambient temperature. The results indicate that the actuation behavior of the droplet is strongly influenced by a heat source. The actuation velocity of the liquid droplet initially accelerates, and then goes down rapidly. During the actuation process, the thermocapillary vortices inside the droplet on the receding side is always smaller than that on the advancing side. The isotherms inside the droplet are notably distorted by the thermocapillary convection. The DCA of the droplet alternates versus time due to the pressure difference acting on the droplet. The ACA first increases rapidly and then decreases continuously while the RCA first decreases strongly and then increases significantly. The ACA is always larger than the RCA during the actuation process.

\section{ACKNOWLEDGEMENT}

The research is supported by DCSELAB and funded by Vietnam National Foundation for Science and
Technology Development (NAFOSTED) under grant number 107.99-2017.317. We acknowledge the support of time and facilities from Ho Chi Minh City University of Technology (HCMUT), VNU-HCM for this study.

\section{ACRONYM}

LOC: Lab-on-a Chip devices

MEMS: Micro-Electro-Mechanical System

SCA: static contact angle

DCA: dynamic contact angle

$\mathrm{CAH}$ : contact angle hysteresis

RCA: The receding contact angle

ACA:Advancing contact angle

\section{CONFLICT OF INTEREST}

This study is done by our self and there have not any results in this paper come from other sources.

\section{AUTHOR'S CONTRIBUTION}

All authors contribute to this study are as the same.

\section{REFERENCES}

1. Haeberle S, Zengerle R. Microfluidic platforms for lab-ona-chip applications. Lab Chip. 2007;7:1094-1110. PMID: 17713606. Available from: https://doi.org/10.1039/b706364b.

2. Yu F, Ai L, Dai W, Rozengurt N, Yu H, Hsiai TK. MEMS thermal sensors to detect changes in heat transfer in the preatherosclerotic regions of fat-fed New Zealand white rabbits. Ann Biomed Eng. 2012;39:1736-1744. PMID: 21380571. Available from: https://doi.org/10.1007/s10439-011-0283-8.

3. Wang L, Sun K, Hu X, Li G, Jin Q, Zhao J. A centrifugal microfluidic device for screening protein crystallization conditions by vapor diffusion. Sensors and Actuators B: Chemical. 2015;219:105-111. Available from: https://doi.org/10.1016/j. snb.2015.04.105.

4. Nguyen N, Wereley S. Fundamentals and applications of microfluidics. Artech House, Boston. 2006;.

5. Nguyen N, Lassemono S, Chollet F. Optical detection for droplet size control in microfluidic droplet-based analysis systems. Sensors and Actuators B. 2006;117:431-436. Available from: https://doi.org/10.1016/j.snb.2005.12.010.

6. Brochard F. Motions of droplets on solid surfaces induced by chemical or thermal gradients. Langmuir. 1989;5:432-438. Available from: https://doi.org/10.1021/la00086a025.

7. Chen J, Troian S, Darhuber A, Wagner S. Effect of contact angle hysteresis on thermocapillary droplet actuation. J Appl Phys. 2005;97:014906. Available from: https://doi.org/10.1063/ 1.1819979.

8. Ford M, Nadim A. Thermocapillary migration of an attached drop on a solid surface. Phys Fluids. 1994;6:3183-3185. Available from: https://doi.org/10.1063/1.868096.

9. Le T, Chen J, Shen B, Hwu F, Nguyen H. Numerical investigation of the thermocapillary actuation behavior of a droplet in a microchannel. Int J Heat Mass Transfer. 2015;83:721-730. Available from: https://doi.org/10.1016/j. ijheatmasstransfer.2014.12.056.

10. Le T, Chen J, Hwu F, Nguyen H. Numerical study of the migration of a silicone plug inside a capillary tube subjected to an unsteady wall temperature gradient. Int J Heat Mass Transfer. 2016;97:439-449. Available from: https://doi.org/10.1016/ j.ijheatmasstransfer.2015.11.098. 
11. Nguyen $N$, Huang $X$. Thermocapillary effect of a liquid plug in transient temperature fields. J Appl Phys. 2005;44:1139-1142. Available from: https://doi.org/10.1143/JJAP.44.1139.

12. Liu H, Valocchi A, Zhang Y, Kang Q. Lattice Boltzmann phasefield modeling of thermocapillary flows in a confined microchannel. J Comput Phys. 2014;256:334-356. Available from: https://doi.org/10.1016/j.jcp.2013.08.054.

13. Le T, Chen J, Nguyen H. Numerical study of the thermocapillary droplet migration in a microchannel under a blocking effect from the heated wall . Appl Thermal Eng. 2017;122:820830. Available from: https://doi.org/10.1016/j.applthermaleng. 2017.04.073.

14. Vincent $M$, Wunenburger $R$, Delville J. Laser switching and sorting for high speed digital microfluidics. Applied Physics Letters. 2008;92:154105. Available from: https://doi.org/10. $1063 / 1.2911913$

15. Olsson $E$, Kreiss $G$. A conservative level set method for two phase flow. J Comput Phys. 2005;210:225-246. Available from: https://doi.org/10.1016/j.jcp.2005.04.007.

16. Olsson E, Kreiss G, Zahedi S. A conservative level set method for two phase flow II. J Comput Phys. 2007;225:785-807. Available from: https://doi.org/10.1016/j.jcp.2006.12.027.

17. Brackbill J, Kothe D, Zemach C. A continuum method for modeling surface tension. J Comp Phys. 1991;100:335-354. Avail- able from: https://doi.org/10.1016/0021-9991(92)90240-Y.

18. Chen J, Kuo C, Neitzel G. Numerical simulation of thermocapillary nonwetting. Int J Heat Mass Transfer. 2006;49:4567-4576. Available from: https://doi.org/10.1016/j.ijheatmasstransfer. 2006.04.033.

19. Tabeling P. Investigating slippage, droplet breakup, and synthesizing microcapsules in microfluidic system. Phys Fluids. 2010;22:021302. Available from: https://doi.org/10.1063/1. 3323086.

20. Koplik J, Banavar JR, Willemsen JF. Molecular dynamics of fluid flow at solid surfaces. Phys Fluids A. 1989;1:781-794. Available from: https://doi.org/10.1063/1.857376.

21. Nguyen $\mathrm{H}, \mathrm{Chen} \mathrm{J}$. A numerical study of thermocapillary migration of a small liquid droplet on a horizontal solid surface. Phys Fluid;22(2010):062102. Available from: https://doi.org/ $10.1063 / 1.3432848$.

22. Nguyen $\mathrm{H}$, Chen J. Numerical study of a droplet migration induced by combined thermocapillary-bouyancy convection. Phys Fluid. 2010;22:122101. Available from: https://doi.org/10 1063/1.3524822.

23. Nguyen HB, Chen JC. Effect of slippage on the thermocapillary migration of a small droplet. Biomicrofluidics. 2012;6:012809. PMID: 22662076. Available from: https://doi.org/10.1063/1. 3644382 . 


\title{
Nghiên cứu sự chuyển động mao dẫn nhiệt của giọt nước trong kênh dẫn micro dưới tác dụng của nguồn nhiệt
}

\author{
Lê Thành Long ${ }^{1}$, Jyh Chen Chen ${ }^{2}$, Nguyễn Huy Bích ${ }^{3}$
}

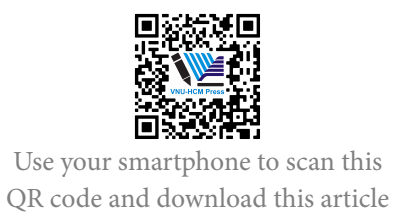

${ }^{1}$ Khoa cơ khí, trường Đại học Bách khoa, ĐHQG-HCM, Việt Nam

${ }^{2}$ Khoa Cơ Khí, Đại học Quốc Gia Trung Ương Đài Loan, Jhongli 320, Taiwan

${ }^{3}$ Khoa Cơ Khí Công nghệ, trường Đại học Nông lâm TPHCM, Việt Nam

Lịch sử

- Ngày nhận: 12/10/2018

- Ngày chấp nhận: 24/11/2018

- Ngày đăng: 31/12/2019

DOI : 10.32508/stdjet.v3iSI1.716

\section{Check for updates}

\section{Bản quyền}

๑) ĐHQG Tp.HCM. Đây là bài báo công bố mở được phát hành theo các điều khoản của the Creative Commons Attribution 4.0 International license.

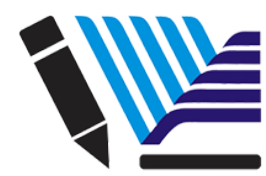

VNU-HCM Press

\begin{abstract}
TÓM TẮT
Sự chuyển động của vi giọt chất lỏng đã và đang phát triển trong hơn hai thập kỷ vừa qua vì những ứng dụng của nó trong công nghiệp và công nghệ cao như hệ thống vi cơ điện tử, chíp sinh học, chuyển động lưu chất và nhiều chuyển động khác. Có nhiều nghiên cứu trong lĩnh vực này tạo ra lực tác đông vi giọt chuyển động từ nhiều nguồn năng lượng khác như nhiệt, từ, áp suất, điện laze và những nguồn khác. Trong nghiên cứu này, phương pháp số được sử dụng để mô phỏng sự chuyển động mao dẫn nhiệt của giọt nước trong kênh dẫn micro. Để theo dõi sự thay đổi tính chất của bề mặt phân cách giửa hai loại chất lỏng khác nhau, chúng ta sử dụng phương pháp phần tử hữu hạn kết hợp với phương pháp định mức hai pha giải quyết phương trình Navier-Stokes và phương trình năng lượng đối với lưu chất trong kênh dẫn. Trong mô hình vật lý, nhiệt độ cả hai biên trên và biên dưới đêu được thiết lập bằng nhiệt độ môi trường xung quanh. Một nguổn nhiệt có công suất $40 \mathrm{~mW}$ được đặt cách vị trí ban đầu của giọt chất lỏng khoảng $1 \mathrm{~mm}$. Khi nguồn nhiệt bắt đầu hoạt động, ta quan sát thấy có 1 cặp dòng xoáy đối lưu mao dẫn nhiệt xuất hiện bên trong giọt nước và ở đây dòng xoáy ở phía trước nhỏ hơn dòng xoáy ở phía sau. Biến thiên nhiệt độ bên trong giọt nước tăng nhanh vào thời gian đầu và sau đó giảm dần theo thời gian. Do đó, vận tốc giọt chất lỏng tăng mạnh lúc đầu và đến khi đạt được vận tốc lớn nhất thì sau đó vận tốc chất lỏng sẽ giảm liên tục. Góc tiếp xúc của giọt nước chịu ảnh hưởng lớn bởi sự dịch chuyển dòng dầu và chênh lệch mao dẫn nhiệt bên trong giọt nước. Trong suốt quá trình chuyển động của giọt nước bên trong kênh dẫn micro, góc tiếp xúc phía sau của giọt nước luôn luôn lớn hơn góc tiếp xúc phía trước.
\end{abstract}

Từ khoá: Mô phỏng số, dịch chuyển mao dẫn nhiệt, kênh dẫn micro, sức căng bề mặt, nguồn nhiệt
Trích dẫn bài báo này: Thành Long L, Chen Chen J, Huy Bích N. Nghiên cứu sự chuyển động mao dẫn nhiệt của giọt nước trong kênh dẫn micro dưới tác dụng của nguồn nhiệt. Sci. Tech. Dev. J. - Eng. Tech.; 2(SI1):Si1-SI8. 